\title{
Glacial dispersal of heavy minerals in late Wisconsinan till, central New Brunswick
}

\author{
E.R.C. Hornibrook, B.E. Broster \\ Department of Geology, University of New Brunswick, P.O. Box 4400, \\ Fredericton, New Brunswick E3B 5A3, Canada \\ W.W. Gardiner and A.G. Pronk \\ Department of Natural Resources and Energy, Mineral Resources Division, P.O. Box 6000, \\ Fredericton, New Brunswick E3B 5H1, Canada \\ Date Received September 20, 1991 \\ Date Accepted October 31, 1991
}

\begin{abstract}
Drift prospecting surveys in New Brunswick have previously had limited success in recognizing dispersal plumes through geochemical or mineralogical analyses of tills. This study was undertaken in the Todd Mountain - Trout Lake area of central New Brunswick to define possible constraints on glacial dispersal and assist in related prospecting activities. Dispersal patterns for specific heavy minerals in the silt to fine sand $(0.125 \mathrm{~mm}-0.250 \mathrm{~mm})$ fraction of 63 till samples were investigated over a $12 \mathrm{~km} \times 25 \mathrm{~km}$ area. Twelve minerals, confirmed by Scanning Electron Microscopy, were selected for study on the basis of local geology and ease of recognition.

In this area of New Brunswick, eastward-trending dispersal plumes can be distinguished over short distances $(<5$ $\mathrm{km}$ ) only for rare indicator minerals that characterize specific sources (e.g., coticules or zircon grains). When sampled at intervals of $100 \mathrm{~m}$ the mineral dispersal patterns more clearly reflect the nature and trend of units in the bedrock. Correlations between mineral content and geochemistry are poor because of glacial mixing of variable source materials. Some poor chemical correlations may also be due to weathering and hydromorphic dispersion. In this area of central New Brunswick, prospecting programs utilizing the fine-grained till fraction require close sample spacing and accurate identification of till facies.
\end{abstract}

Les levés de prospection par les dépôts glaciaires au Nouveau-Brunswick ont auparavant rencontré des succès mitigés dans la reconnaissance des patrons de dispersion glaciaire par les analyses géochimiques ou minéralogiques des tills. La présente étude a été entreprise dans la région mont Todd - lac Trout, dans le centre du Nouveau-Brunswick, afin de fournir des données sur la dispersion glaciaire et d'assister les activités de prospection associées. Les patrons de dispersion de certains minéraux lourds dans la fraction silt à sable fin $(0.125 \mathrm{~mm}-0.250 \mathrm{~mm})$ de 63 échantillons de till ont été étudiés pour une région de $12 \mathrm{~km}$ par $25 \mathrm{~km}$. Douze minéraux, dont l'identification a été confirmée par microscopie électronique, ont été choisis pour l'étude en raison du contexte géologique et de leur facilité d'identification.

Pour cette région du Nouveau-Brunswick, il est possible de distinguer des patrons de dispersion de direction est, sur de courtes distances $(<5 \mathrm{~km})$, seulement pour de rares minéraux indicateurs caractéristiques de certaines sources (comme les grains de coticule ou de zircon). A des intervalles d'échantillonage de $100 \mathrm{~m}$, les patrons de dispersion minéraux reflètent plus nettement la nature et l'orientation des unités du socle. La corrélation entre le contenu en minéraux et la composition géochimique est faible en raison du mélange glaciaire de matériaux de diverses sources. Il y a de faibles corrélations géochimiques qui peuvent aussi être dues à l'altération superficielle et à la dispersion par l'eau souterraine. Dans cette région du centre du Nouveau-Brunswick, les programmes d'exploration qui utilisent la fraction fine du till nécessitent une grille d'échantillonage serrée et une identification précise des faciès du till.

[Traduit par le journal]

INTRODUCTION

Knowledge of the nature of glacial dispersal is essential when conducting mineral exploration in areas of glaciated terrain. Only if this information is known are lithologic or geochemical surveys useful in identifying exploration targets. In this regard, the present study was undertaken as a pilot project to determine local constraints on the use of heavy mineral ( $S G>2.85$ ) analysis for mineral exploration and geological mapping in central New Brunswick.
Heavy mineral studies have been previously used to advantage in other regions of Canada (e.g., Derry, 1933; Gravenor, 1951; Dreimanis and Vagners, 1971; Shilts, 1976; Gwyn and Dreimanis, 1979; Hicock, 1988; Coker and Dilabio, 1989) but have received only minor attention in the Maritimes. In the past, this has been due mainly to the complex patterns of ice movement (e.g., Seaman, 1991), extensive sediment reworking and deglacial cover. Additional problems have been the lack of reliable indicators or 
distinctive and point source lithologies that could be clearly distinguished as a mineral source.

In till, a dispersal train or plume is a ribbon or fan-shaped zone enriched in debris from an up-ice source relative to the surrounding till (e.g., Dreimanis, 1958; Shilts, 1976; Peuraniemi, 1987; Coker and DiLabio, 1989). A dispersal plume is commonly recognized by contouring concentrations of distinctive clastic or matrix components of the till. The main objective of our study was to determine the approximate nature and length of heavy mineral dispersal patterns downice of known mineralized sources. Secondary objectives were: (1) to access the potential of various heavy minerals as indicators of bedrock provenance; and (2) to examine relationships between heavy minerals and a recent geochemical survey.

\section{Geology of the study area}

Bedrock investigations in the Todd Mountain - Trout Lake area of central New Brunswick (Fig. 1) reveal lithologic and mineralogic occurrences that were regionally distinctive and particular to this area. The area comprises metasedimentary and metavolcanic rocks of the Tetagouche Group which have been intruded by late Devonian granites and are in faultcontact with the Magaguadavic slates (Kingsclear Group) of Silurian age (Poole, 1963; MacLellan et al., 1990).

Todd Mountain lies within a thin NE-SW oriented zone of low grade metamorphosed Ordovician shales and siltstones $\left(\mathrm{Os}_{1}\right.$; Fig. 1). The zone contains black shales, a metamorphosed red manganiferous siltstone (spessartine-rich) and minor mafic tuffs. The zone is in contact with the Upper Devonian Trout Lake granite to the north.

Coticule is the term for a rock consisting primarily of spessartine garnet with a sericite or quartzite matrix (Kennan, 1986). Because of its suspected genetic relationship with the formation of volcanogenic massive sulfide deposits, coticule has been suggested as a potential exploration guide to base metal deposits (Kennan, 1986). Part of the metasedimentary (MS) unit (Os unit; Fig. 1) has been identified as a coticule member (locally referred to as the coticule horizon) with some similarity to ore-bearing Ordovician rocks of the Bathurst mining camp in New Brunswick (Gardiner and Venugopal, personal communication, 1990).

MacLellan et al. (1990) indicated that tin, tungsten, and minor base metal mineralization occurs along the Todd Mountain MS zone within a SE-NW trending fracture and fault system. The fault system may have developed within and above the apical portion of the Trout Lake pluton. Mineralization is both endo- and exogranitic, and the mineralizing hydrothermal fluids were likely magmatically derived.

MacLellan et al. (1990) described the Trout Lake granite as a subcircular epizonal, post-orogenic pluton. It is a texturally variable polyphase intrusion dominated by biotite monzogranite. Features of the pluton include: (1) sharp, discordant intrusive contacts; and (2) a narrow contact aureole with local zones of intense hydrothermal alteration.
Geochemically, the pluton is characterized as a mildly peraluminous, high-silica granite. It has been found to contain low concentrations of $\mathrm{CaO}, \mathrm{MgO}, \mathrm{P}_{2} \mathrm{O}_{5}, \mathrm{TiO}_{2}, \mathrm{Ba}, \mathrm{Eu}$, and $\mathrm{Sr}$, and high concentrations of $\mathrm{Cs}, \mathrm{Nb}, \mathrm{Ta}, \mathrm{Th}, \mathrm{U}, \mathrm{W}, \mathrm{Y}$ and of particular interest, Sn (MacLellan et al., 1990).

Base metal mineralization has been known to occur in the study area for some time. MacLellan et al., (1990) described cassiterite-bearing veins that crop out on Todd Mountain, oriented between $115^{\circ}$ and $120^{\circ}$, parallel to the regional joint trend. Vein mineralization includes quartz, muscovite, beryl, iron-rich biotite (annite), iron-rich chlorite (chamosite), clay minerals, arsenopyrite, cassiterite, and allanite (MacLellan et al., 1990).

At Trout Lake Brook, tin-rich greisen boulders, as well as high $\mathrm{Sn}$ and $\mathrm{U}$ geochemical anomalies, led to the discovery of cassiterite-bearing greisen lenses from $30 \mathrm{~cm}$ to $4 \mathrm{~m}$ wide that parallel the regional jointing trend. This was informally referred to as the "greisen zone" by MacLellan et al. (1990). Aplite dykes and beryl-bearing pegmatitic pods occur in the granite associated with the greisen zone. The greisen zone at Trout Lake seems to be linear and extend towards Todd Mountain, thus serving as a distinctive target that can be readily traced by geochemistry or heavy mineral dispersion.

\section{Previous work}

Quaternary mapping has been conducted in the area by Rampton and Paradis (1981) and Lamothe (1990a; 1990b). According to Rampton et al. (1984) much of the Todd Mountain area is covered by a discontinuous bouldery veneer (less than $0.5 \mathrm{~m}$ thick) of late Wisconsinan age. The cover is up to $3.0 \mathrm{~m}$ thick in some areas overlying the Trout Lake granite. The cover is believed to consist primarily of lodgement till, with minor ablation till, silt, sand, gravel, and rubble (Rampton et al., 1984; Lamothe, 1990a). Fluted bedrock, drumlinoid ridges, and glacial striae indicate that glacial flow was eastward prior to deglaciation of the area (Fig. 1).

Previous dispersal studies in the study area have examined heavy mineral distribution in stream sediments (Poole and LaChance, 1964) and element dispersal in till (Lamothe, 1990b). Poole and LaChance (1964) used x-ray fluorescence spectroscopy to study placer pan concentrates. Their objective was to confirm that tin and tungsten minerals were associated with the Devonian intrusives. This relationship has subsequently been supported by later more detailed studies (Brule, 1982; Jensen, 1986). Still, several factors are worth noting from their early investigation.

Poole and LaChance (1964) report that in the stream sediments: (1) cassiterite was not readily identified in the field, (2) zirconium distribution roughly parallelled yttrium distribution, (3) radioactivity of untreated concentrates showed a weak correlation with zirconium, yttrium, tin, and tungsten, and (4) in their opinion, manganese was mainly concentrated near the granitic terrains. However, observations of their maps show low Mn values immediately overlying the granites, while concentrations are notably elevated at and just 


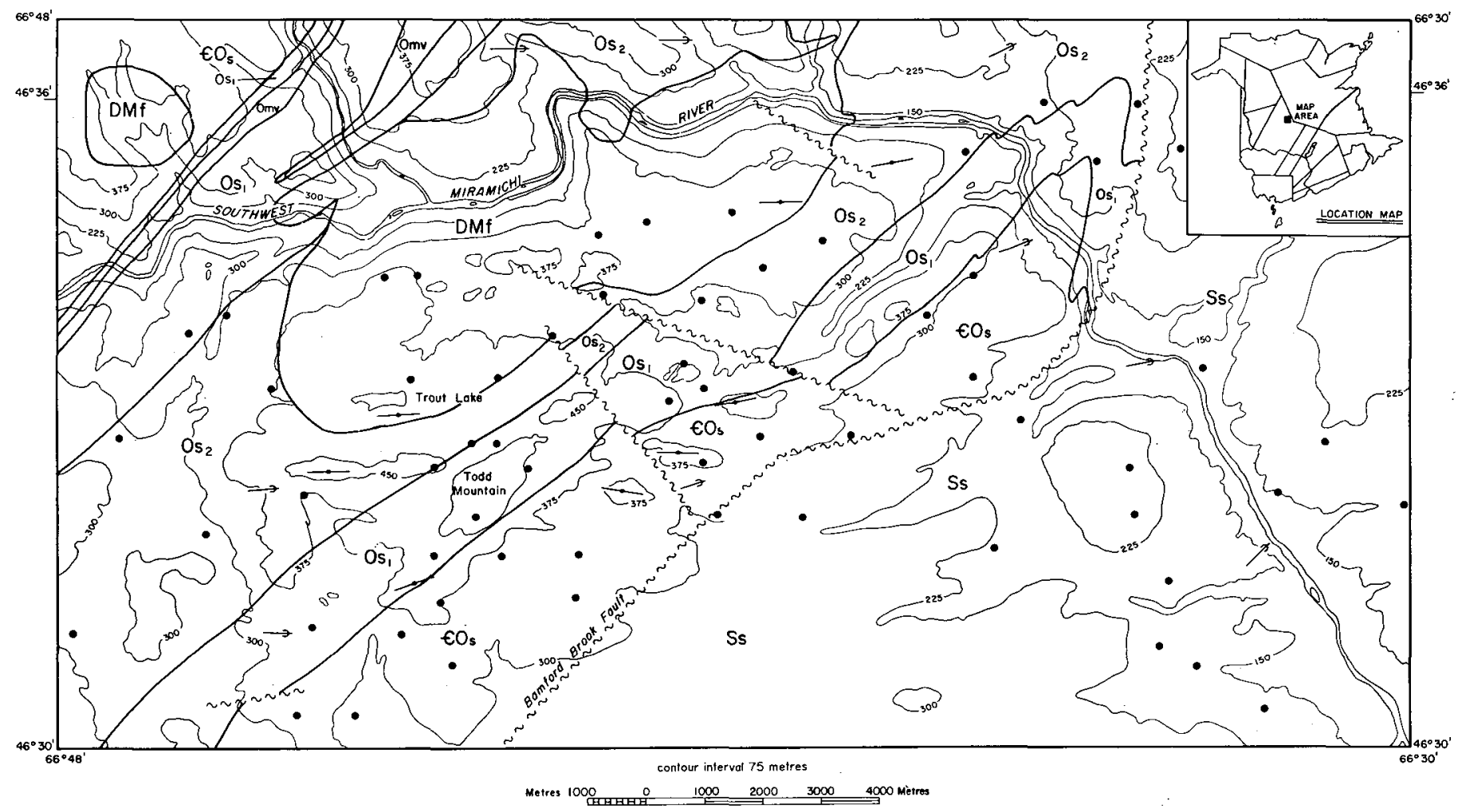

Fig. 1. Study area indicating $75 \mathrm{~m}$ contours, elongated landforms $(-\sim)$, striae directions $(\rightarrow)$, sample locations $(\bullet)$, faults $(\sim)$ and bedrock lithologies, including: Ordovician quartzose greywacke, siltstone ( $€$ Os), Ordovician mafic volcanic flows (Omv), Ordovician black slate and ferromagnesian slate $\left(\mathrm{Os}_{1}\right)$, Ordovician lithic greywacke and siltstone $\left(\mathrm{Os}_{2}\right)$. Silurian quartzose greywacke, slate (Ss), Devonian granite (DMf). Area location within the province of New Brunswick is indicated ( $\square$ ) in the county map insert.

below locations where streams cut the Os, (Todd Mountain) horizon. Their manganese results were likely due to lack of information about garnetiferous quartzites (coticule) at that time. They speculated that high Mn values "...probably reflect manganese-bearing garnets from metamorphic rocks." (Poole and LaChance, 1964).

Under terms of the 1984-89 Canada-New Brunswick Mineral Development Agreement, regional till geochemical surveys were conducted in the Miramichi Zone of New Brunswick (Fig. 1). From 1985 to 1988, M. Lamothe carried out extensive till sampling over several map sheets in central New Brunswick. Lamothe's objective was to use detailed geochemistry in the vicinity of known mineral occurrences as a data base to interpret regional surveys, in terms of geochemical response and dispersal. Resulting reports (Lamothe, 1990a, 1990b) dealt primarily with specific element analyses. Mineralogy was not employed in quantitative results. Nevertheless, Lamothe (1990b) was able to distinguish dispersal plumes on the order of a few hundred meters in length by utilizing close sample-spacing.

\section{Samples and preparation}

Sixty-three sub-samples were obtained from samples previously collected by Lamothe (1990b) during a Geological Survey of Canada investigation of regional till geochemistry. The samples are considered to represent basal till deposited during the late Wisconsinan (Lamothe, 1990b). One hundred and twenty-three samples were initially selected for analysis. However, during further treatment of the samples, approximately one half of the specimens did not yield enough heavy minerals for polished epoxy grain mounts.

Sub-samples used in our study were reduced to their heavy mineral fraction through a series of separations involving panning, shaker table, and heavy liquids. Initial wet sieving was performed to obtain mineral sizes ranging from silt to medium-sand size. Previous investigations (e.g., Dreimanis and Vagners, 1971; Gwyn and Dreimanis, 1979) found this clast fraction to be the most diagnostic when studying subglacial dispersal of several minerals or minerals from multilithological sources in Ontario.

Sample concentrates were obtained using a "gold hound (wheel)" and gravity table as preliminary methods of bulk separation. From comparative tests, this preliminary step was found to increase the efficiency of the heavy liquid separation. Due to the abundance of phyllosilicates found in preliminary runs (Hornibrook, 1991), final separation was accomplished using two heavy liquids: (1) bromoform (SG 2.89) and (2) tetrabromoethane (SG 2.96). Magnetite was removed prior to final separation by means of a hand held magnetic separator, weighed, and later calculated in terms of parts per million (ppm) per bulk sample.

Representative portions were then prepared as polished epoxy grain mounts. Initial mineral identifications were made 
optically using standard techniques associated with transmitted and reflected light microscopy (e.g., relief, colour, form, habit, birefringence and bireflectance, anisotropism, interference figures, a limited number of textural features such as exsolution, twinning, etc.). Grain mounts were scanned by the "Line Method" (e.g., Galehouse, 1969) which is a relatively rapid method for quantitative mineralogical tabulation. The method enables a slide to be advanced under the ocular cross hairs at regular intervals, thus ensuring a consistent and representative examination of the entire slide, irrespective of grain size or uneven distribution on the slide.

When ambiguities arose, identifications were confirmed by $\mathrm{x}$-ray diffraction spectroscopy and/or Scanning Electron Microscopy (SEM) using an energy dispersive system (EDS). All grain counts were eventually conducted optically once mineral identification was confirmed.

\section{Statistics}

The number of observations (counts) per slide required for a realistic estimate of dispersal was determined through a statistical analysis of the modal mineral abundances in the incremental counting of sample groups. Six slides representing samples from locations throughout the study area were selected for initial mineral identification. Four hundred grains were examined in eight groups of 50 grain counts each. Abundances and cumulative abundances were calculated and normalized to frequency percent for the 13 mineral types identified.

A plot of cumulative frequency percent with total grain count (Fig. 2) indicated that modal abundance became more consistent after 200 grain counts. For counts from 50 to 200 the cumulative percentages tend to be very erratic. At about 200 to 250 counts the percentages become more consistent and approach values achieved by higher grain counts. Statistical analyses (Hornibrook, 1991) also confirmed that grain counts of 200 to 250 were not significantly different from total counts of 400 . From these observations it was inferred that consistent results, and thus an accurate estimate, could be achieved with 250 counts per sample.

The statistical analyses were performed on STATGRAPHICS@ version 4.0. Data reduction was performed using LOTUS 1-2-3@. SURFER $\odot$ was used to plot sample coordinates and contour mineral frequencies of the 63 specimens. Mineral relationships were investigated by calculation of Pearson's correlation coefficient between normalized counts of individual mineral types, mineral groups, and the chemical analyses from Lamothe's (1990b) study (see Hornibrook, 1991).

\section{Analysis and Results}

\section{Heavy minerals}

Many of the economic minerals (cassiterite, scheelite, wolframite, and base metal sulfides) and associated minerals (fluorite, zircon, tourmaline, rutile, ilmenite, garnet, and iron
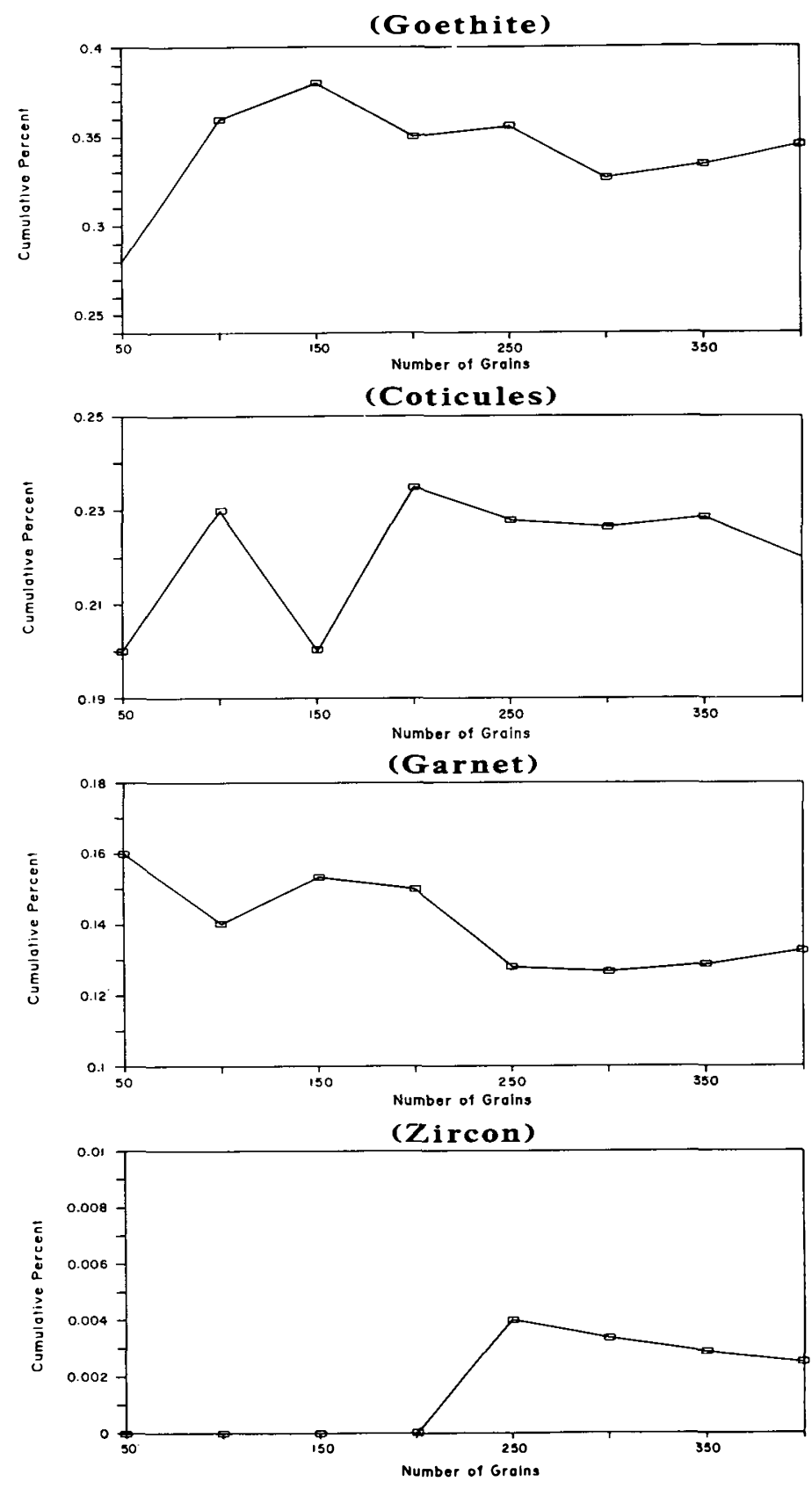

Fig. 2. Results of tests to determine the number of grains to be examined for consistent values. Counts were recorded as cumulative groups of 50 . Note relative stabilization of quantities after counting 200 to 250 grains.

oxides) have a specific gravity greater than 2.85 (the "heavy" minerals; Einhart et al., 1973). Most heavy minerals are strongly resistant to chemical and physical weathering in the near surface environment. Some exceptions are: the sulfides which readily oxidize; as well as scheelite and wolframite which are brittle and disintegrate early during transport (Luepke, 1984).

Certain heavy minerals can be useful in the deciphering of till provenance; owing to their general durability which permits them to withstand long glacial transport. They are thus useful for indicating particular source areas and are a 
common and readily-studied constituent of tills (Dreimanis, 1958; Fenton and Dreimanis, 1976; Gwyn and Dreimanis, 1979).

\section{Minerals studied}

The preliminary investigation of the mineralogy in the samples (Hornibrook, 1991) resulted in 13 separate mineral groups being distinguished, including: coticules and whole garnets (clear and green), zircons (clear and zoned), hematite/goethite, ilmenite/magnetite, sillimanite/fibrolite, cassiterite, amphibole, tourmaline, epidote, and unknown translucent and opaque minerals. Unknown opaque minerals were further examined under reflected light; metallic opaques (e.g., pyrite, bornite) are discussed more fully elsewhere (Hornibrook, 1991).

At least 25 optically distinguishable minerals were present in the samples. The major types are discussed below in order of significance to the present study.

\section{Garnet}

Garnet appears to be confined to till overlying the Todd Mountain metasedimentary unit (MS; Os; ; Fig. 1) and thus served as an indicator mineral. Garnets were separated into groups of coticules (garnet aggregates) and whole garnets. The coticules consist of spessartine garnets in a quartzite matrix and less commonly, chlorite.

Whole garnets in the area are mainly spessartine with a lesser to equal component of almandine. Whole garnets commonly have dark inclusions of what appear in reflected light to be metallic minerals (e.g., native tin). This was confirmed in several grains where the inclusions were sufficiently large to allow positive identification by SEM. Inclusions of grey opaques were observed that consist of varying amounts of vanadium, titanium, manganese and iron. Similar inclusions were also identified in sillimanite and pyroxenes.

\section{Zircon}

Zircon is useful as an indicator of up-glacier granitic sources such as the Trout Lake pluton. Both "zoned" and "clear" zircons were readily identified in transmitted light due to their extreme birefringence (and hence bright display of interference colours). Also, the zoned zircons possess distinctive and well-defined crystal habits.

\section{Goethite}

Goethite is present as red transparent grains exhibiting internal layering that closely resembles the zoning found in cassiterite in the samples studied. In addition, grains commonly exhibit regular crystal edges and internal features which resemble twinning. Goethite commonly occurs as deep red colloform masses with either a regular or irregular habit. Some "zoned crystals", with goethite surrounding a core of sulphide, has resulted from pyrite replacement (Fig. $3)$.

\section{Other}

Ilmenite was easily identified because of its distinctive exsolution textures. The fibrous variety of sillimanite was readily identified in reflected light due to its distinctive texture and high birefringence. The fibrolitic masses commonly contained large dark inclusions of the V-Ti-Mn-Fe oxides.

Cassiterite is abundant in weathered soil samples taken directly from the outcrop surface at Todd Mountain. However, only minor occurrences in the till samples did not warrant this mineral to be counted as a distinct group. When the mineral was observed, it was found as small fragments only.

Amphiboles are abundant in grain mounts and were counted as a separate group. However, they were ultimately found to provide very little useful information on local sources.

Mineral grains that appeared to be gold or electrum were subsequently identified by SEM as a tin-lead alloy. Further research is being done on the possibility of the mineral having been introduced during sample preparation.

In addition to pyrite, several other sulfides were observed in the samples, although, they were present in minor quantities only, which did not justify counting them as individual groups. Pyrrhotite was found in both the magneticallyseparated fraction and in thin sections from heavy mineral separates, possibly indicating the presence of both ferromagnetic (monoclinic) and non-magnetic (hexagonal) pyrrhotite varieties. Several grains of bornite (copper iron sulfide, $\mathrm{Cu}_{5} \mathrm{FeS}_{4}$ ), were observed that commonly exhibited extensive covellite (CuS) alteration. A few grains of chalcopyrite were also noted.

\section{Dispersal patterns}

Other than goethite (Fig. 3), many of the heavy minerals present in the Todd Mountain area are apparently resistant to chemical and physical weathering. Under the microscope, neither garnet nor zircon crystals are extensively eroded or broken. Their crystal faces are normally intact, showing only minor polish and lacking degradation features (Fig. 4). From these observations we infer: (1) glacial erosion, (2) a short transport distance, and (3) deposition as subglacial till.

Most minerals (e.g., cassiterite, tourmaline, ilmenite, amphibole, sillimanite, and epidote) did not exhibit any meaningful relationships with respect to provenance, topography, or glaciation of the area. Three exceptions are: zircon, garnet and goethite.

Zircons and garnets show the strongest affinities to specific up-glacier source areas. High concentrations of zircons were found in samples from till directly overlying the Trout Lake pluton (Fig. 5). Contoured zircon percentages 


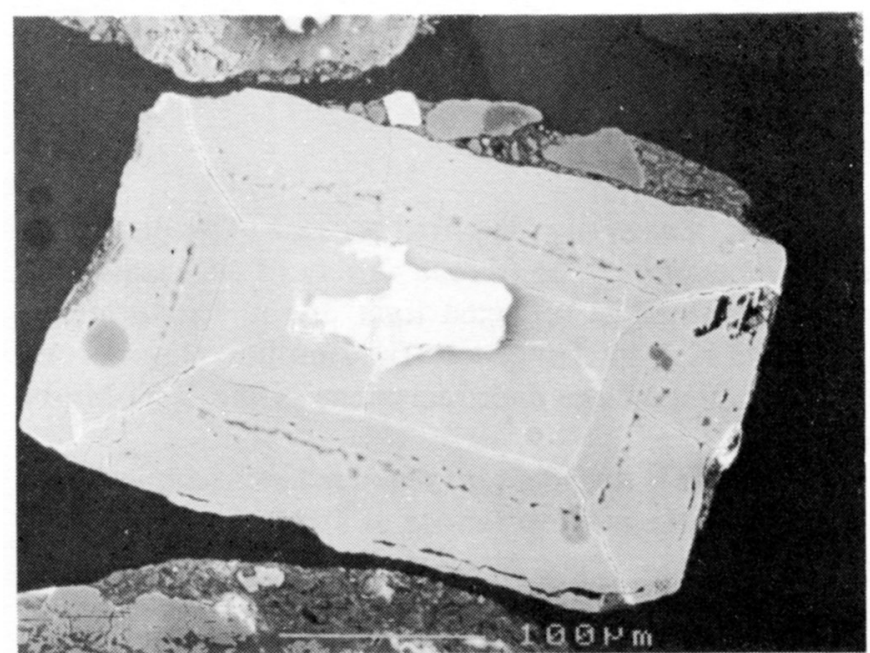

Fig. 3. SEM image of zoned crystal with secondary goethite surrounding a core of pyrite.

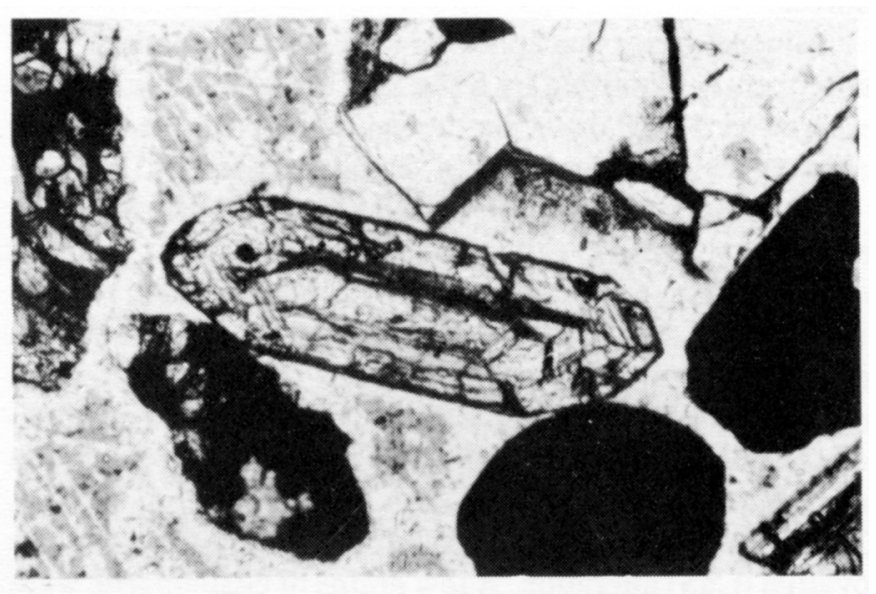

Fig. 4. Photomicrograph (approximately $220 \mu$ wide) of zircon grain under transmitted light; note subangular edges of grain.

exhibit consistently low concentrations along the Todd Mountain MS horizon, while at other locations across the area there is a somewhat erratic distribution of low zircon occurrences (Fig. 5). Conversely, whole garnets and coticules together show a good relationship with the Todd Mountain MS marker unit. The gamet-rich samples plot almost exclusively along the length of the northeast-southwest trending MS unit (Fig. 6). Garnet dispersal plumes are traceable for distances on the order of several hundred metres to a maximum of about $3 \mathrm{~km}$ and are directed due east (cf. Shilts, 1976) parallel to local striae directions.

While the zircon values overlying the Trout Lake pluton are high, the length of the dispersal plume is relatively short $(<1.5 \mathrm{~km})$ in comparison to $3.0 \mathrm{~km}$ garnet dispersal plume at Todd Mountain (Figs. 5, 6). For this particular case, we attribute the difference in dispersal length to topographic influences on glacial processes rather than to differences in mineral resistance during glacial comminution or to differ- ences in size of outcrops exposed to glaciation. Data for both minerals demonstrate small regular changes that coincide with relatively flat areas, while the highest values for garnet and lowest for zircon, are associated with the higher elevations at Todd Mountain (Figs. 5, 6).

Todd Mountain, a competent garnet-bearing quartzite, forms a resistant bedrock ridge that represents the dominant positive landform in the area. The only other significant geomorphological feature is the depression formed by the southwest Miramichi River valley, which bounds the study area to the north and east. In the northeast portion of the area, Todd Mountain rises $120 \mathrm{~m}$ above the surrounding area. Here, the glacier would have experienced more obstruction to flow than elsewhere. Thus, anomalously-high amounts of garnet-rich material, relative to the material from the Trout Lake area, may have been incorporated because erosion was preferentially concentrated at subglacial obstructions.

Contour highs for goethite also parallel the Todd Mountain unit to the southeast (Fig. 7), but we believe this to have been influenced in part by hydromorphic dispersion. Goethite was likely formed by oxidation and re-precipitation of iron from mobilizing groundwater as indicated by the zoning and pyrite replacement (Fig. 3), discussed earlier. This may have been initiated during the Pleistocene by fluid flow concentrated along the Bamford Brook Fault (Hicock, personal communication, 1991). Sulfide minerals in the Todd Mountain MS horizon provide iron to ground and surface waters. Iron-rich water presently migrates down the southeast flank of the topographic high and in the past may have precipitated iron along the base of the hill. The greater abundance of organic matter, and hence reducing conditions in the low region, has likely contributed to goethite formation (Rose $e t$ al., 1979).

\section{Correlations}

Correlations between mineral frequency and geochemical data from Lamothe (1990b) were examined for the entire study area, as well as for three areal blocks related to specific bedrock lithologies, including: the area to the northwest of the Todd Mountain MS unit, the linear MS unit, and the area southeast of the MS unit. Correlation coefficients (not included) between Lamothe's (1990b) geochemical data and the mineral frequencies presented here were generally of low significance.

Poor chemical correlations may be influenced in part by weathering and hydromorphic dispersion or by samples not uniformly collected from basal till. Poor correlations between chemical and mineral fractions are not uncommon and several researchers (e.g., Dreimanis and Vagners, 1971) have noted that locally-incorporated lithic components of basal tills are typically more abundant in the coarser size fractions, in contrast to that of the finer fractions which commonly retain more distantly-derived material. An exception can occur because of entrainment of local fine-grained waterlain deposits (e.g., Broster, 1986). Either situation would in part, 


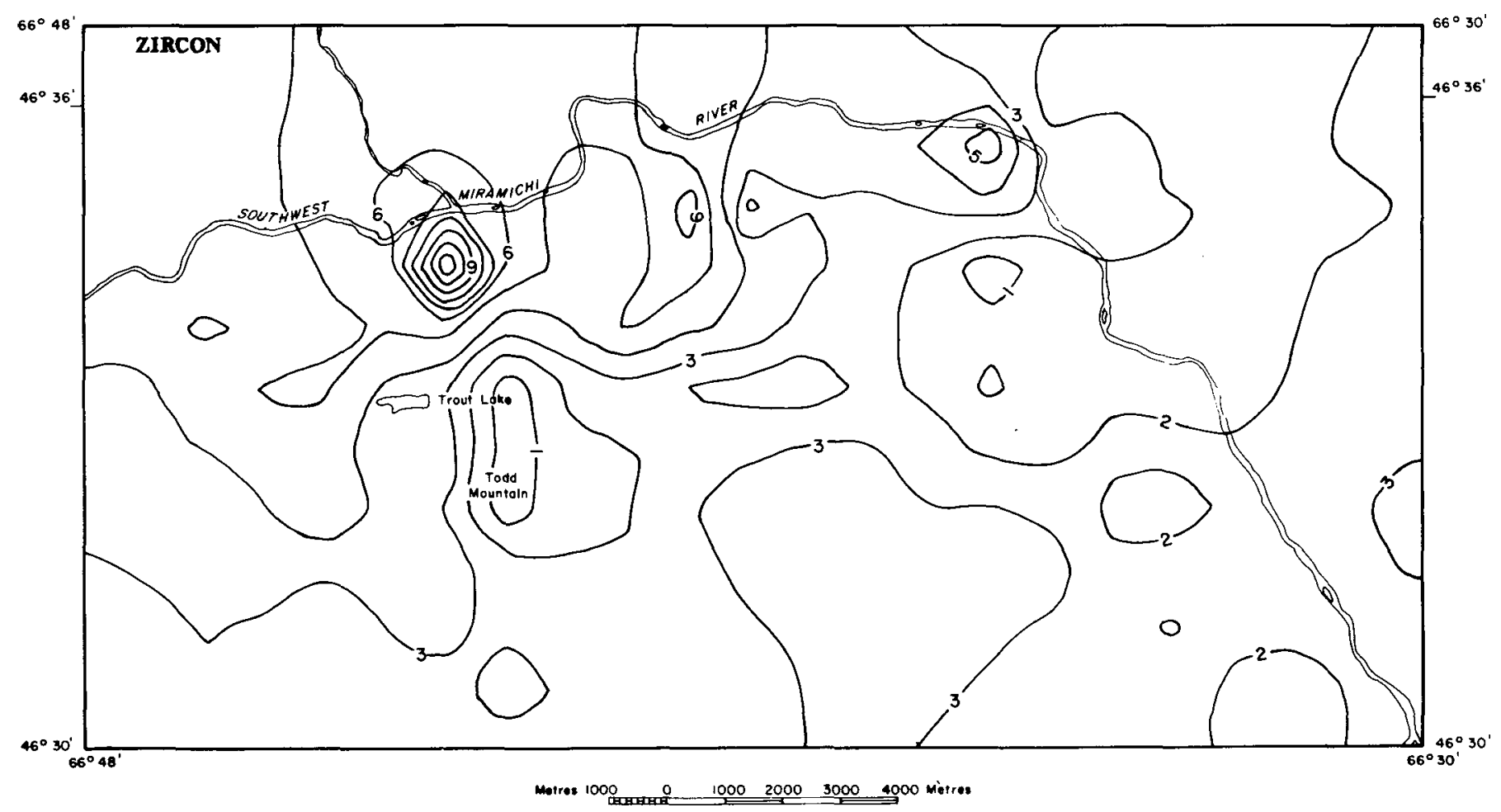

Fig. 5. Contoured values for zircon data showing high counts associated with the granite bedrock in the Trout Lake area; note gradual decrease in zircon towards the southeast.

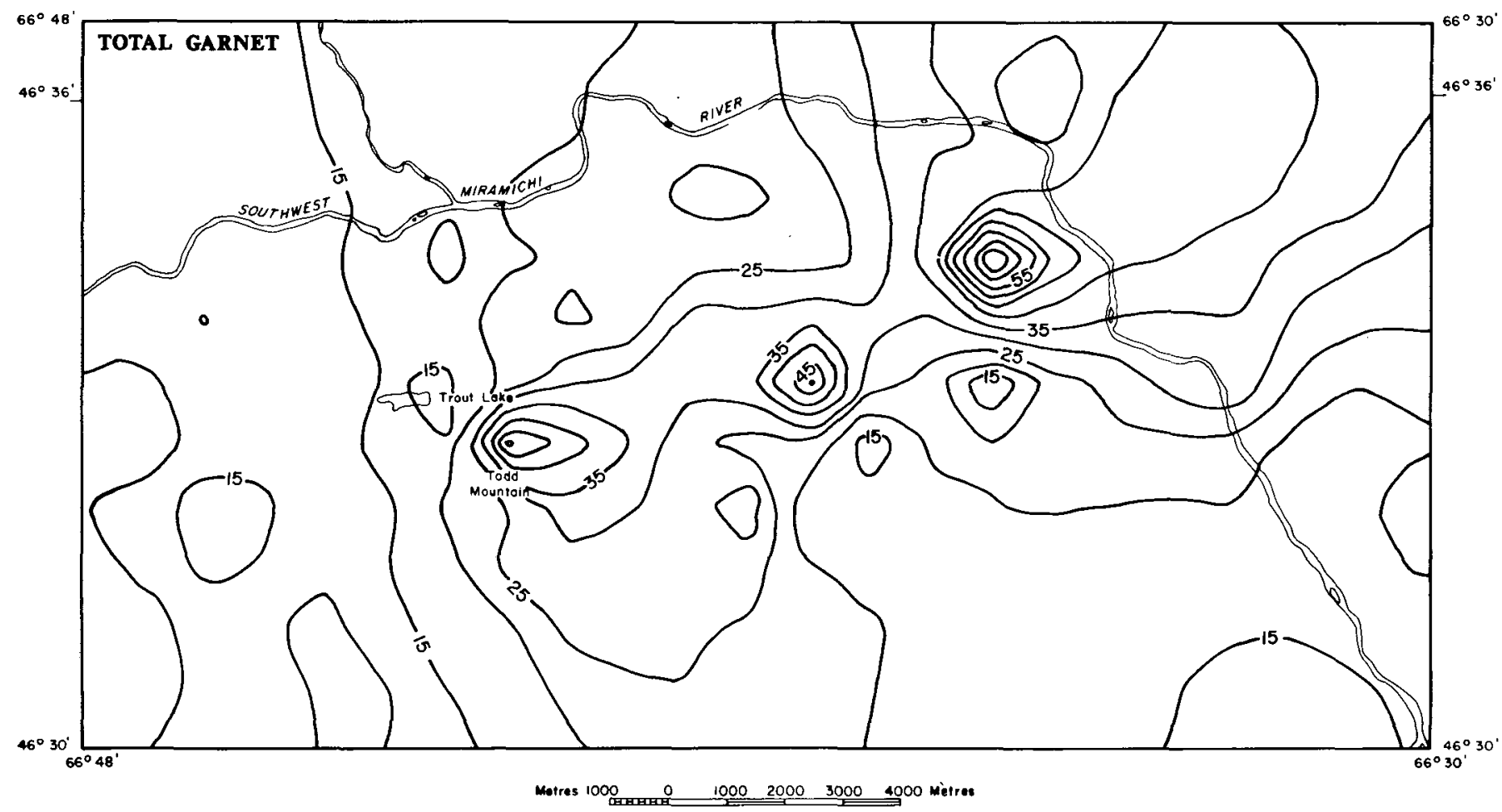

Fig. 6. Contoured values for total garnet data showing high counts originating along the Todd Mountain metasedimentary unit (Os, Fig. 1) and correlation of high concentrations downglacier of points of high elevation (Fig. 1). 


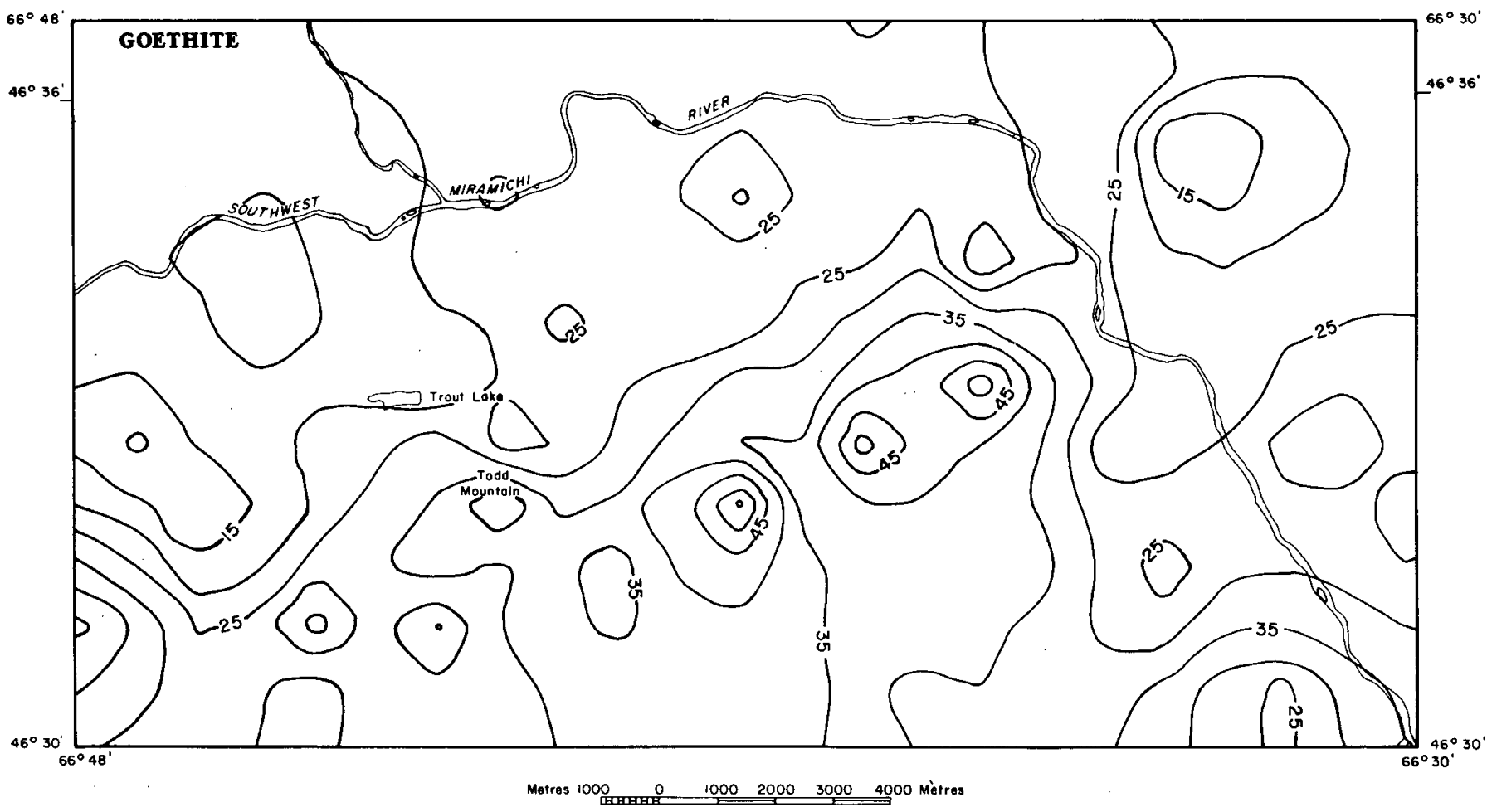

Fig. 7. Contoured values for goethite data with highest counts occurring downslope and downglacier of Todd Mountain.

account for poor correlations between our heavy mineral analysis of the medium sand-course silt fraction and Lamothe's geochemical analysis on silt and clay $(<63 \mu)$.

Although heavy minerals were of similar grain size, these were also found to demonstrate poor statistical correlations among the minerals studied. Because of their areal relationships, as demonstrated by the contour data, a strong inverse relation between zircon and garnet was expected. However, this proved to be statistically insignificant.

Poor mineral correlations may be due to thorough glacial mixing (cf. Broster, 1986) and/or derivation of material from many different sources (cf. Dreimanis and Vagners, 1971), both of which obscure genetic relationships and tend to confuse mineral correlations (Broster, 1986). To the north and south of the Todd Mountain MS horizon, mineral correlations are likely poor because of variable lithologies that occur (Fig. 1). Glacial transport of distally-derived material up over the topographic high at Todd Mountain probably resulted in mixing with material locally entrained along the ridge due to local compressive flow and upshearing (cf. Hicock, 1988) and further confused mineral correlations in the till at this location and southeastward.

\section{Conclusions}

A study of the heavy mineral fraction in the tills from the Todd Mountain area, central New Brunswick, revealed that distinctive geologic units may be readily traced using specific indicator minerals. The Todd Mountain MS unit can be traced using either whole garnets or garnet aggregates (cotic- ules), but is particularly well defined by contour maximums for total garnets (Fig. 6). This may prove to be useful in future exploration of this unit which shows potential for further $S n$, $\mathrm{W}$, and other base metal occurrences.

In this area, resistant minerals were glacially dispersed over short distances only. Glacial comminution may explain a decrease in abundance of less-competent minerals (e.g., cassiterite). However, fresh-looking mineral habits, incorporated from local units, support the interpretation that the samples analyzed probably represent basal entrainment and limited comminution and transport.

The difference in length of dispersal plumes could be due to a number of causes. The distinctive and longer garnet dispersal plume (relative to zircon) is attributed to greater glacial erosion and entrainment at Todd Mountain because of its projection as a topographic high, into overriding ice. These conditions may have been accentuated by local compressive flow and glacial upshearing. Glacial erosion and entrainment in areas of moderate relief have short dispersal plumes of $<3 \mathrm{~km}$ in length. Although heavy mineral dispersal plumes may reach lengths of 3 to $4 \mathrm{~km}$ where the point of origin has been a topographic projection into overriding ice, future prospecting programs utilizing the fine-grained till fraction will require close sample-spacing (not exceeding 100 to $250 \mathrm{~m}$ apart) and accurate identification of till facies.

Studies commonly report that, in central New Brunswick, basal tills contain mainly locally-derived material (Broster and Seaman, 1991), suggesting short dispersal plumes for geochemical $(<1.0 \mathrm{~km}$, Lamothe, 1990b) or for clast fractions $(<14 \mathrm{~km}$, Balzer and Broster, 1991). The short 
plume lengths in our area could be due to a variety of causes, including: (a) slow moving ice because of proximity to ice divides, similar to examples in Finland discussed by Puranen (1990, pp. 31-32), or other confines; (b) erosion and transport by a cold based glacier; or (c) extensive mixing of local and far travelled materials, so that dilution of the glacier load quickly obscured the dispersal fan. Further research is necessary to clarify the underlying cause(s) of short dispersal fans in this region.

\section{ACKNOWLEDGEMENTS}

The authors wish to thank Drs. S.R. Hicock and R.A. McGinn for their review of an earlier draft and their helpful comments. Funding was provided to Hornibrook from the Minerals Branch of the New Brunswick Department of Natural Resources (NBDNR) and through an NSERC University Undergraduate Research Award. Drafting, geochemical analysis and microscopy were funded by NBDNR operating budgets to Gardiner and Pronk; and by NSERC Operating Grant A1886 to Broster.

BALzer, S.A. and Broster, B.E. 1991. Glacial dispersion of clast lithologies: Lake George area, New Brunswick. Canadian Quaternary Association, 1991 Biennial Meeting, Conference Abstracts, Atlantic Geology, 27, p. 230.

Broster, B.E. 1986. Till variability and compositional stratification: examples from the Port Huron lobe. Canadian Journal of Earth Sciences, 23, pp. 1823-1841.

Broster, B.E. and Seaman, A.A. 1991. Glacigenic rafting of weathered granite: Charlie Lake, New Brunswick. Canadian Journal of Earth Sciences, 28, pp. 649-654.

Brule, D. 1982. Project 535, Trout Lake claim group (21J/10E), New Brunswick, 1981 field program. Eldorado Nuclear Limited Report. New Brunswick Department of Natural Resources and Energy, Minerals and Energy Division, Assessment File 472809.

Coker, W.B. and Dilabio, R.N.W. 1989. Geochemical exploration in glaciated terrain: Geochemical responses. In Proceedings of Exploration '87, Ontario Geological Survey, Special Volume 3, pp. 336-383.

Derry, D.R. 1933. Heavy minerals of the Pleistocene beds of the Don Valley, Toronto, Ontario. Journal of Sedimentary Petrology, 3, pp. 113-118.

Dreimanis, A. 1958. Tracing ore boulders as a prospecting method in Canada. Canadian Mining and Metallurgical Transactions, 61, pp. 49-56.

Dreimanis, A. and Vagners, U.J. 1971. Bimodal distribution of rock and mineral fragments in basal tills. In Till / a symposium. Edited by R.P. Goldthwait. Ohio State University Press, Columbus, Ohio, pp. 237-250.

Einhart, N., Volker, D., and Wolf-Dieter, G. 1973. Contributions to sedimentology: Stability of heavy minerals. E. Schweizerbart'sche Verlagsbuchhandlung (Nagele u. Obermiller) Stuttgart, Germany, $125 \mathrm{p}$.

Fenton, M.M. and Dreimanis, A. 1976. Methods of stratigraphic correlation of till in central and western Canada. In Glacial Till: An interdisciplinary study. Edited by R.F. Legget. Royal Society of Canada, Special Publication Number 12, pp. 67 82.
Galehouse, J.S. 1969. Counting grain mounts: number percentage vs. number frequency. Joumal of Sedimentary Petrology, 39. pp. 812-815.

Gra VenOR, C.P. 1951. Bedrock source of tills in southwestern Ontario. American Journal of Science, 249, pp. 66-71.

Gwyn, Q.H.J. and Dreimanis, A. 1979. Heavy Mineral Assemblages in Tills and Their Use in Distinguishing Glacial Lobes in the Great Lakes Region. Canadian Journal of Earth Science, 16, pp. 2219-2235.

Hicock, S.R. 1988. Calcareous till facies north of Lake Superior, Ontario: implications for Laurentide ice streaming. Géographie Physique et Quaternaire, 42, pp. 120-135.

Hornibrook, E.R.C. 1991. Glacial dispersion in the Todd Mountain area, New Brunswick. New Brunswick Department of Natural Resources, Minerals Division, OFR 91-11, 125 p.

Jensen, L. 1986. Trout Lake (21J/10E), New Brunswick. Kidd Creek Mines Limited Report. New Brunswick Department of Natural Resources and Energy, Minerals and Energy Division, Assessment File 473268.

Kennan, P.S. 1986. The Coticule Package: A Common Association of some very Distinctive Lithologies. Aardkundige Mededelingen, 3, pp. 139-148.

LAMothe, M. 1990a. Till geochemistry in the vicinity of the late Devonian granites of the Hayesville area, Central New Brunswick: A trenching project. Geological Survey of Canada, Open File 2217, 54 plates, 66 p.

1990b. Till geochemistry over the Central Miramichi Zone and Vicinity, New Brunswick. Geological Survey of Canada, Open File 2237, 106 p.

LUEPKE, G. 1984. Stability of heavy minerals in sediment. Van Nostrand Reinhold, New York, 306 p.

Maclellan, H.E., Taylor, R.P., and Gardiner, W.W. 1990. Geology and Geochemistry of Middle Devonian Burnthill Brook Granites and related Tin-Tungsten Deposits, York and Northumberland Counties, New Brunswick. New Brunswick Department of Natural Resources and Energy, Mineral and Energy Division, Mineral Resources Report 4, 95 p.

Peuraniemi, V. 1987. Interpretation of heavy mineral results from till. In INQUA Till Symposium, Finland 1985. Edited by R. Kujansuu and M. Saarnisto. Geological Survey of Finland, Special Paper 3, 194 p.

Poole, W.H. 1963. Hayesville map area, New Brunswick. Geological Survey of Canada, Map 6-1963.

Poole, W.H. and LAChance, G.R. 1964. Placer pan concentrates, Hayesville and Napadogan map areas, $(21 \mathrm{~J} / 10,7)$, Central New Brunswick. Geological Survey of Canada, Open File Report 617.

Puranen, R. 1990. Modelling of glacial transport of tills. Chapter 2, In Glacial Indicator Tracing. Edited by R. Kujansuu and M. Saarnisto. A.A. Balkema Publishers, Netherlands, pp. 15-32.

Rampton, V.N. and Paradis, S. 1981. Quatemary geology of Woodstock Map Area (21J), New Brunswick. New Brunswick Department of Natural Resources and Energy, Minerals and Energy Division, Map Report 81-1, 37 p.

Rampton, V.N., Gauthier, R.C., Thibault, J., and Seaman, A.A. 1984. Quaternary geology of New Brunswick. Geological Survey of Canada, Memoir 416, 77 p.

Rose, A.W., HAwKes, H.E., and WeBB, J.S. 1979. Geochemistry in mineral exploration, 2nd edition. Academic Press, New York, $657 \mathrm{p}$.

Seaman, A.A. 1991. Complex glacial ice-flow events in New Brunswick with particular reference to the Oromocto Lake 
area and implications for drift prospecting. Geoscience Report 89-2, New Brunswick Department of Natural Resources and Energy, Mineral and Energy Division, 40 p.

SHILTs, W.W. 1976. Glacial till and mineral exploration. In Gla- cial Till: An interdisciplinary study. Edited by R.F. Legget. Royal Society of Canada, Special Publication Number 12, pp. 205-224. 